Homme Wedman

\title{
HET PANAMA-SCHANDAAL (1889-1893)
}

\section{DE STAAT, DE STRAAT EN DE BOOSDOENERS}

Op 4 februari r889 werd het faillissement van de Compagnie Universelle du Canal Interocéanique de Panama uitgesproken. De telegraaf verspreidde het nieuws over de gehele wereld. De meeste kranten openden met het opzienbarende nieuws. Voor de meer dan 80.000 aandeelhouders in Frankrijk, in Europa en Amerika was het nieuws dramatisch. Zo zag in ons land de 'God van Gaasterland', jonkheer J.H.F.K. van Swinderen, filantroop, grootgrondbezitter, burgemeester en Eerste-Kamerlid, zijn fortuin verschrompelen. Dat was voor een aanzienlijk deel belegd in aandelen van de Panama-maatschappij. Na het faillissement werd hij gedwongen grote gedeelten van zijn omvangrijke ZuidFriese bezit te gelde te maken.

Behalve de omvang van de financiële debacle was ook het stranden van een tot de verbeelding sprekend project als de verbinding tussen twee wereldzeeën een aspect dat de val van de Compagnie Universelle tot een belangrijk nieuwsfeit maakte. De betrokkenheid van Gustave Eiffel, de bouwer van de net gereedgekomen toren in Parijs en van Ferdinand de Lesseps, de bouwer van het Suez-kanaal, vergrootte de persaandacht.

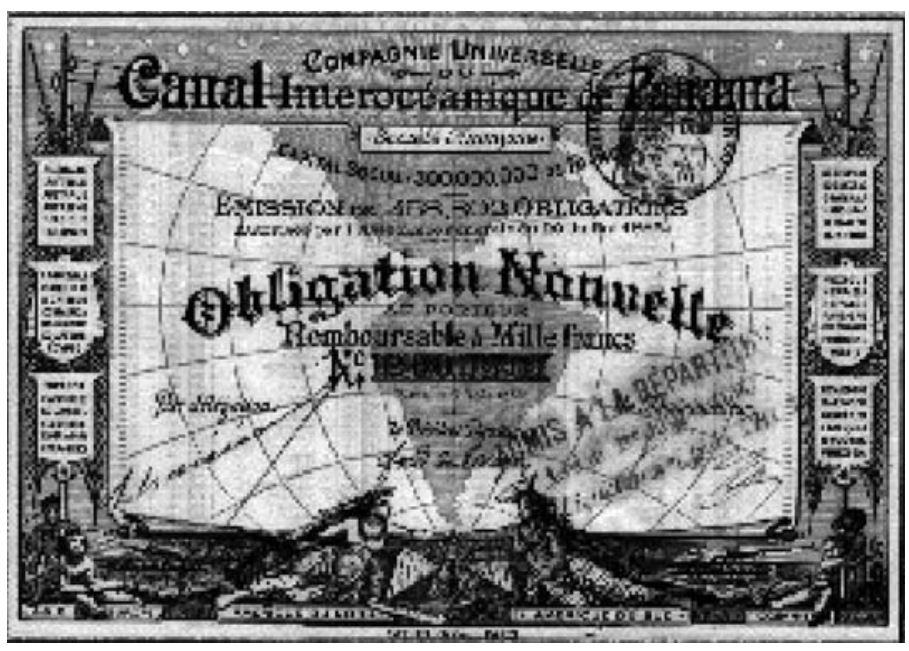

Aandelen van de Compagnie Universelle du Canal Interocéanique. Bron: www.scripophilie.com/temoignages/ canal_panama.htm

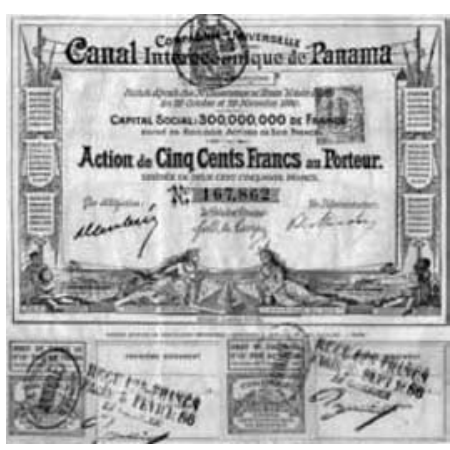


Op zichzelf genomen was het faillissement van de Universele Panama-maatschappij in I889, hoe ingrijpend voor vele betrokkenen ook, niet een uitzonderlijke gebeurtenis. In eigen land kennen we de Tulpenmanie van I630-1637, die overigens volgens een recente studie heel wat minder heftig en omvangrijk

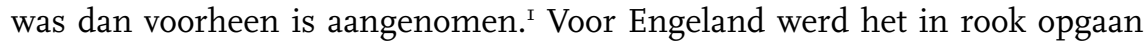
van de waarde van aandelen vooral geassocieerd met de South Sea Bubble van I720. Tegenwoordig heet dit speculatieschandaal wel de Engelse Enron-affaire, vernoemd naar het gelijknamige recent ondergegane Amerikaanse bedrijf, waarvan de directie een veel te rooskleurige voorstelling van zaken gaf van de onderliggende waarde van de aandelen. Een recent voorbeeld van een barstende 'bubble' is ook de windhandel in aandelen in internetbedrijven in de periode I995-200I. Wat het Panama-schandaal doet uitsteken boven gewone speculatieschandalen is enerzijds de diepgaande betrokkenheid van de pers en de politieke en financiële elite bij de zaak en anderzijds de heftige reactie die het bekend worden daarvan had in de vergaderzalen van de Derde Franse Republiek, in de pers, in de cabarets en op straat. In die reacties waren - afzonderlijk of gemengd - felle tonen van nationalisme, links en rechts antisemitisme en antiparlementarisme te horen. In de Dreyfus-affaire zou het Panama-schandaal voor wat het antisemitisme betreft zijn vervolg krijgen. Maar het is niet juist om het Panama-schandaal slechts als aanloop van die moeder van alle schandalen te zien.

\section{Het tweede kanaal}

Een scheepvaartverbinding tussen de Atlantische en de Stille Oceaan was een oude droom, lange tijd slechts te realiseren door een lange, zware tocht via Kaap Hoorn. De groei van de Verenigde Staten in westelijke richting, culminerend in de inlijving van Californië in I848, deed de belangstelling voor een snellere verbinding over zee tussen Oost- en Westkust toenemen. In de jaren I850-I855 leidde dit tot de aanleg van een spoorverbinding over het smalste deel van de landengte van Panama. Die onderneming had leerzaam kunnen zijn voor degenen die een kanaal wilden realiseren. De aanleg over het moeilijk begaanbare spoortraject kostte twaalfduizend arbeiders het leven. De meesten stierven aan de cholera of malaria.

De aanleg van het Suez-kanaal tussen de Middellandse Zee en de Indische Oceaan stimuleerde de belangstelling voor een kanaal in Midden-Amerika. Het I7I kilometer lange Suezkanaal werd tussen I859-I869 gegraven. De opening - opgeluisterd met de première van Verdi's Aida - kreeg veel publiciteit in de West-Europese pers, met name in de Franse. Het kanaal was in hoofdzaak een Franse onderneming, totdat in I875 de Engelsen de aandelen van de onderkoning van Egypte overnamen. De ontwerper van het Suezkanaal, Ferdinand de Lesseps kreeg grote bekendheid en hij werd in I879 door een internationaal 
comité - door hemzelf voorgezeten - aangewezen als constructeur van een verbinding tussen de Atlantische en de Stille Oceaan. Hij was toen al 74 jaar oud. In I88 r richtte hij de naamloze vennootschap Compagnie Universelle du Canal Interocéanique de Panama op die begon met de uitvoering. Het werk vorderde moeizaam. Het traject van 77 kilometer, parallel aan de al bestaande spoorlijn, leidde langs bergachtige en moerassige gebieden. De Lesseps hield vast aan zijn plan voor een kanaal zonder sluizen. Onder de arbeiders, vooral Japanners en Jamaicanen, brak malaria en gele koorts uit. In de periode-de Lesseps werden ongeveer vierentwintigduizend doden geregistreerd. Banken wilden geen leningen meer verstrekken en de directie van de Compagnie Universelle gaf telkens nieuwe aandelen uit. De koers daarvan manipuleerde men door tal van journalisten te betalen voor gunstige publiciteit. In I887 was het werk tot de helft gevorderd, wat met de plannen overeenkwam. Maar de kosten waren van de begrote 600 miljoen franc - die de Lesseps eind I880 al binnengehaald had - in totaal nu al opgelopen tot I400 miljoen. Uitgeschreven obligatieleningen werden niet voltekend. Daarop werd de beroemde ingenieur Gustave Eiffel aangetrokken. Die bevond zich op de top van zijn roem met het voltooien van de Eiffeltoren ter gelegenheid van de Parijse Wereldtentoonstelling van I889. Eiffel herzag de kanaalplannen door er sluizen in op te nemen. Dat zijn naam aan de onderneming verbonden werd hield het vertrouwen enige tijd hoog. Ter financiering werden tal van parlementsleden omgekocht om te stemmen voor een wet, die het uitschrijven van een enorme obligatielening met loterij toestond. De betrokken ministers die de wet opstelden, waren eveneens van geldelijke besproeiïng voorzien. Zij waren op de hoogte van een onderzoek uit I886, dat de positie van de Compagnie Universelle onhoudbaar had genoemd. Enkele bankiers, die wisten van de werkelijke situatie, verdienden goed aan de uitgeschreven lening van 760 miljoen franc en aan 'bemiddelingkosten' bij het omkopen van politici en journalisten. Die lening werd uiteindelijk nog niet voor de helft voltekend, waarop de zeepbel barstte. Op 4 februari i 889 werd de Compagnie Universelle failliet verklaard. ${ }^{2} \mathrm{Na}$ eindeloze verwikkelingen zouden de Amerikanen het kanaal afbouwen in I9I4, 33 jaar nadat de eerste schop in de grond was gegaan. Franse investeerders hadden de schrik goed te pakken gekregen. Ze gingen beleggen in veilige waardepapieren, zoals de door de Russische regering gegarandeerde spoorwegaandelen. In I9I7 was ook dat sprookje uit.

\section{Het tweede schandaal}

De aandacht voor de ondergang van de Compagnie de Panama bleef bestaan omdat medio I89I het vooronderzoek in de rechtszaken tegen de directie van de Compagnie Universelle en een aantal andere betrokkenen van start ging. De profiteurs van het bedrog werden in de periode wel als 'chèquards' aangeduid. Het eerste proces betrof de directie van de Panama-onderneming wegens 
bedrog, misleiding en frauduleus handelen, de tweede rechtszaak betrof omkoping en kende ook Kamerleden en ministers als verdachten. De zaken speelden zich in de eerste maanden van 1893 af. Vooral het corruptieproces trok veel aandacht en was in zekere zin de afsluiting van het tweede Panama-schandaal. Die tweede fase was ingezet met de publicatie van een aantal artikelen in september 1892 in La Libre Parole. Het blad was op 20 april van dat jaar gelanceerd door Edouard Drumont, één van de meest bekende antisemitische auteurs van Frankrijk. Hij had in I886 La France Juive gepubliceerd, dat herdruk na herdruk beleefde. Zijn nieuwe blad wist zich door de Panama-onthullingen goed te verkopen. Drumont beschikte over een goed ingevoerde informant, een vroegere medewerker van de Compagnie Universelle, Ferdinand Martin, die met Drumont onder het pseudoniem 'Micros' nogal indringend aannemelijk maakte, dat veel geld terecht was gekomen bij journalisten, Kamerleden en ook ministers. Cruciaal daarbij was dat La Libre Parole van Drumont en het nationalistische $L a$ Cocarde van Maurice Barrès de aandacht steeds meer wisten te vestigen op de rol van de financiële tussenpersonen van joodse afkomst en die van het grote aantal bij de zaak betrokken politici, van wie de namen gedoseerd werden prijsgegeven.

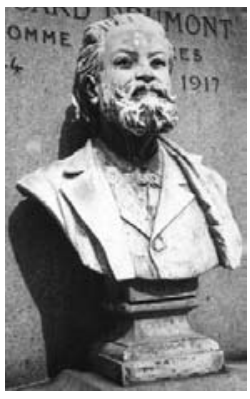

En mai 2006, la Ville de Paris a fait buriner l'épitaphe du tombeau d'Édouard Drumont au Cimetière du Père-Lachaise, considérée comme constituant « un trouble à l'ordre public ». On pouvait y lire : «Édouard Drumont homme de Lettres auteur de l'œuvre immortelle de La France juive ». D'autre part, sur une plaque fixée sur la maison où a habité Edouard Drumont était écrit Ici a vécu Edouard DRUMONT, limmortel auteur de la France Juive, qui avait, dès 1886, prévu le mal dont la France a failli mourir. En reconnaissance et en réparation. Source: documentaire Le Chagrin et la pitié

Het leidde tot een parlementair onderzoek eind 1892 dat de gemoederen verder verhitte. De voorzitter van de Chambre des Députés, Charles Floquet, werd - goed getimed - door La Cocarde ervan beschuldigd 300.000 francs aan cheques te hebben geïncasseerd. Toen de belangrijkste tussenpersoon, Jacques, Baron de Reinach, voor de parlementaire commissie werd gedaagd verscheen hij niet, waarop een arrestatiebevel werd uitgevaardigd. Zijn adjudant Emile Arton - eigenlijk Aäron Arton, zoal de antisemitische pers niet naliet te benadrukken - vluchtte naar het buitenland. De dag daarna, 20 november I892, werd Reinach dood in bed aangetroffen. De lijkschouwer gaf een verklaring van een natuurlijke dood af, wat het schandaal nog verhevigde, vooral toen de verantwoordelijke minister weigerde alsnog opdracht te geven voor een autopsie. Het kabinet-Loubet viel daarop. De andere grote bemiddelaar, Cornélius Herz, was intussen naar Engeland gevlucht en gaf onbekommerd interviews aan de Franse en de internationale pers, waarin hij luidkeels 
zijn onschuld beklemtoonde. Het parlementaire onderzoek leidde niet tot concrete resultaten, maar versterkte de verdenking tegen vele leden van de Kamer van Afgevaardigden, vooral die van het regerende centrum: de 'Opportunistes'. Duidelijk werd dat de leider van de gematigd linkse republikeinen, Georges Clemenceau, veel geld van Reinach had gekregen voor zijn dagblad. De beschuldiging van Drumont leidde tot het voor die tijd gebruikelijke duel, dat onbeslist bleef. Clemenceau had in ieder geval de schijn tegen, hetgeen hem in I893 zijn Kamerzetel kostte. Tijdens de Dreyfus-affaire zou hij langzaam weer boven komen drijven.

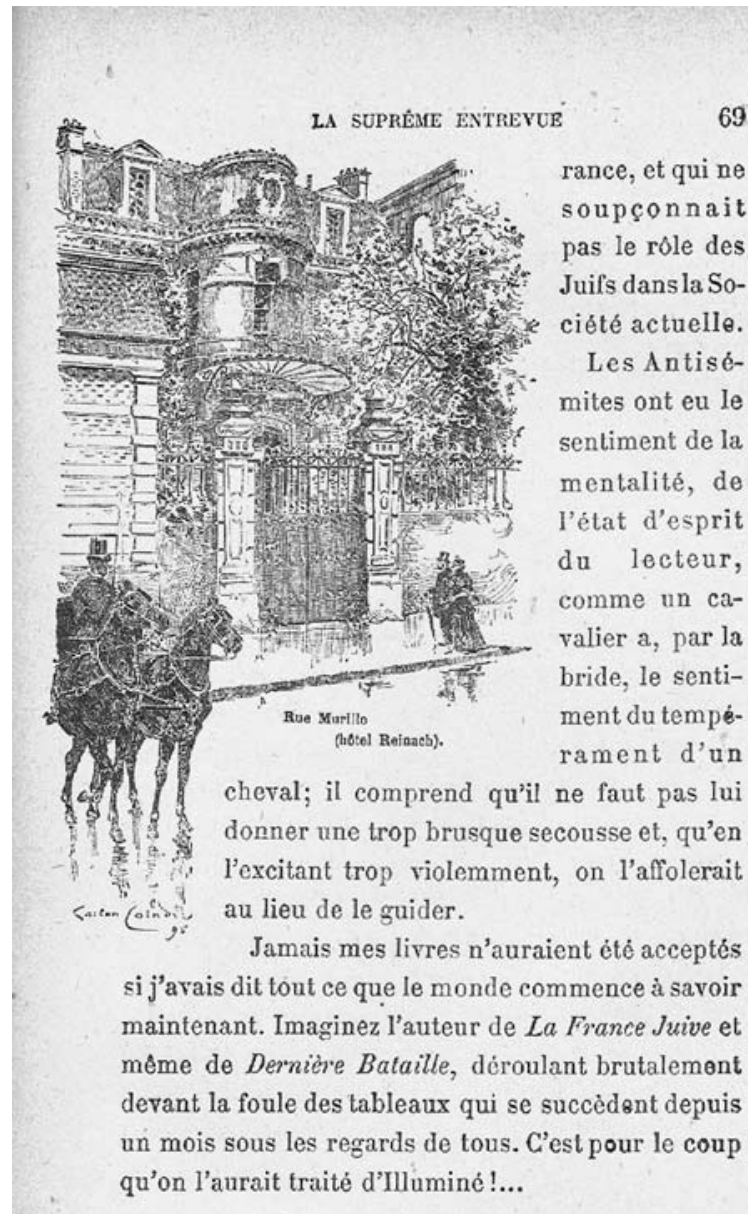

Uit: Édouard Drumont, De l'or, de la boue, du sang, Du Panama à l'anarchie (Flammarion, Parijs 1893). Afgebeeld is de chique woning van Baron de Reinach, hoofdrolspeler in het schandaal
Onder Kamerleden - van meer dan honderd man werd aannemelijk dat ze bij omkoping betrokken waren - vielen heel weinig slachtoffers bij de rechtszaken. Een complicatie bij de bewijsvoering was, dat de betalingen via cheques aan toonder waren verlopen, zodat bij ontkennende verdachte politici aanvullend bewijs nodig was en daar was moeilijk aan te komen, of er werd niet overijverig naar gezocht, zoals Drumont en zijn medestanders beweerden. Alleen een vroegere minister van Arbeid werd veroordeeld, omdat hij zo onverstandig was geweest te bekennen.

Ook in de rechtszaken tegen de bestuurders van de omkopende instantie, de Compagnie Universelle, werd betrekkelijk mild gevonnist. Ferdinand de Lesseps hoefde vanwege zijn leeftijd zijn straf van vijf jaar niet uit te zitten. De vijf jaar voor zijn zoon werd in beroep teruggebracht tot één jaar. Ingenieur Gustave Eiffel werd aanvankelijk wel veroordeeld, maar werd uiteindelijk toch vrijgesproken. Tot 1898 vonden nog enkel kleinere rechtszaken plaats tegen verdachten, maar tot vonnissen met sancties kwam het niet meer. In de publiciteit kregen die zittingen niet al te veel aandacht omdat intussen de Dreyfus-affaire de krantenkolommen en het politieke leven ging beheersen. ${ }^{3}$ 


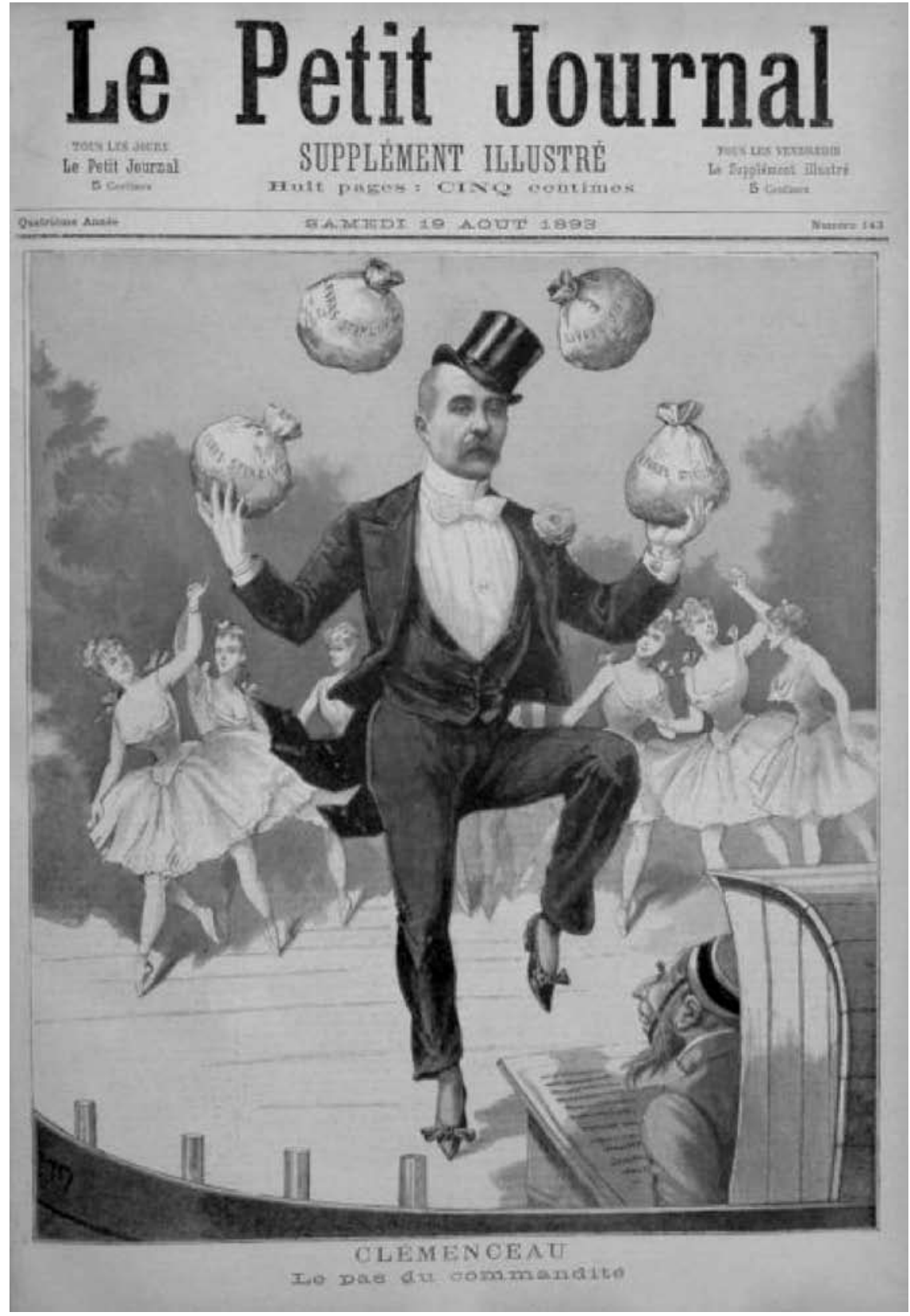

Clemenceau verloor zijn geloofwaardigheid door het ontvangen van gelden van de Compagnie Universelle voor zijn krant.

Bron: www.1ge.org/ documents/ troisiemerepublique/ panama.htm

De affaire als uiting van antisemitisme

De jaren van het Panama-schandaal waren bloei-jaren voor het moderne antisemitisme in Frankrijk. Sinds het midden van de negentiende eeuw ontston- 
den naast het op oude christelijke vooroordelen geïnspireerde katholieke antisemitisme, modernere varianten. Die opkomst vond plaats in een periode waarin de joodse emancipatie, integratie en soms zelfs assimilatie zichtbaar werd. In de Parijse financiële wereld waren joden oververtegenwoordigd, met als symbolisch zwaartepunt de familie Rothschild. In intellectuele en artistieke kringen traden vele joden op de voorgrond. Hetzelfde gold voor de politiek en in wat mindere mate voor het leger. ${ }^{4}$ Tegelijkertijd kwam er vanuit Oost-Europa een emigratie op gang van in taal en uiterlijk duidelijk als joods herkenbare groepen, die zich vooral in Parijs en andere grote steden vestigden. Voor conservatief-katholieke ideologen waren joden van oudsher de archetypische woekeraars, wat naadloos overging in de mythe van het joodse kapitaal dat zijn tentakels uitspreidde over de wereld in het algemeen en Frankrijk in het bijzonder. Verder bleven de oude beschuldigingen van joden als Christusmoordenaars en offeraars van christenkinderen in stand. Het katholieke blad La Croix was ten tijde van het Panama-schandaal en de Dreyfus-affaire de spreekbuis van deze stroming. 5

Net als het socialistische antisemitisme raakte ook het conservatief katholieke antisemitisme na I880 vermengd met modernere wetenschappelijke - of liever gezegd pseudo-wetenschappelijke - inzichten ontleend aan Darwin. De wereld als schouwtoneel van een 'lutte des races' kleurde ook in Frankrijk de verschillende antisemitismen. Maar voor geen land in Europa geldt sterker dan voor Frankrijk het doortrokken zijn van het opkomende socialisme met antijoodse vooroordelen.

De invloedrijkste ideoloog voor de Franse arbeidersbeweging is ongetwijfeld Pierre Joseph Proudhon geweest. Voor hem was de Jood de vreemdeling bij uitstek, de parasiet die verdelgd moest worden. In zijn later uitgegeven Carnets noteerde hij de volgende aantekening:

'Juifs. Faire une article contre cette race, qui envenime tout, en se fourrant partout, sans jamais se fondre avec aucun peuple. - Demander son expulsion de France, à l'exception des individus mariés avec des Françaises. - Abolir les synagogues, ne les admettre à aucune emploi, poursuivre enfin l'abolition de ce culte. Ce n'est pas pour rien que les chrétiens les ont appelés déicides. Le juif est l'ennemi du genre humain. Il faut renvoyer cette race en Asie ou l'exterminer'. ${ }^{6}$

Het is nogal wat, wathier gezegd wordt: in het voorgenomen artikel wil Proudhon aantonen dat het joodse ras alles vergiftigt, dat het zich verstopt zonder ooit samen te smelten met een ander volk; dat het uit Frankrijk verdreven moet worden - uitgezonderd gemengd gehuwden - en dat de synagogen gesloten en de eredienst verboden moeten worden; dat de christenen joden terecht als moordenaars van Christus hebben beschouwd; dat de jood, de vijand van de mensheid, naar Azië moet worden teruggestuurd dan wel vernietigd. 
Even kras als Proudhon uitte zich de utopist Charles Fourier. Diens antijoodse werkzaamheid werd voortgezet door zijn leerling Alphonse Toussenel, wiens werk Juifs rois de l'époque verscheen in I844. Hij schakelde het begrip 'Juif' gelijk aan 'kapitalistische uitbuiter' en betitelde ook protestantse Nederlandse, Engelse en Geneefse ondernemers als mensen die eigenlijk joden waren. Toussenel schetste een samenzwering van de joodse 'haute finance', die het gehele leven in Frankrijk beheerste ten nadele van de arbeider, de boer en de handwerksman. Edouard Drumonts La France Juive van I 886 was in hoge mate schatplichtig aan het werk van de Fourierist Toussenel. La Libre Parole, het blad dat de Panama-afaire in I892 op scherp zette, zou vaak op Toussenel teruggrijpen.

In het Franse socialisme was de invloed van Marx lange tijd betrekkelijk gering. Daarbij speelde dubbele weerzin tegen Marx als Duitser en als Jood een niet onbelangrijke rol. Maar binnen de groep van zijn aanhangers, geleid door Jules Guesde, speelde het door Marx zelf bevorderde antisemitisme een rol. Ook hij identificeerde 'de Jood' met 'de bourgeoisie', 'de kapitalist'. Belangrijker dan de marxistische inspiratie was die van Auguste Blanqui en volgelingen als Gustave Tridon - auteur van Le molochosme juif uit I884, door Drumont hogelijk geprezen - en Albert Regnard. De laatste kon in de periode I887-I889 in het algemeen-socialistische theoretische tijdschrift van Benoît Malon, La Revue Socialiste zeven artikelen publiceren met als thema 'Aryens et Sémites'. Datzelfde blad zou in de jaren van het Panama-schandaal nog vaker bijdragen van linkse antisemieten publiceren.7 Zelfs Jaurès, de later socialistische voorman, die het merendeel van de Franse socialisten in het kamp der Dreyfusards wist te krijgen, schreef

78 DE L'OR, DE LA BOUE, DU SANG

dont on ignore l'origine; ils ne meurent pas, ils disparaissent brusquement dans un drame...

Ils attirent le drame, ils l'apportent avec eux dans les pays qu'ils bouleversent et dans les intérieurs qu'ils envahissent. Le krach, le coup de théảtre ou le coup de Bourse, l'imprévu dans l'interlopie semblent ètre leur naturel élément.

Quand de pareils gaillards sont lâchés dans une Société, comment voulez-vous que les natifs puissent continuer à vivre de la bonne vie tranquille d'autrefois? Ils entrainent tout le monde dans la trépidation de leur mouvement; ils troublent tout autour d'eux par le trouble de leur propre esprit...

En vérité, ces modernes et ces ultracivilisés, avec leurs outrances, leurs fièvres, leurs convoitises toujours allumées,
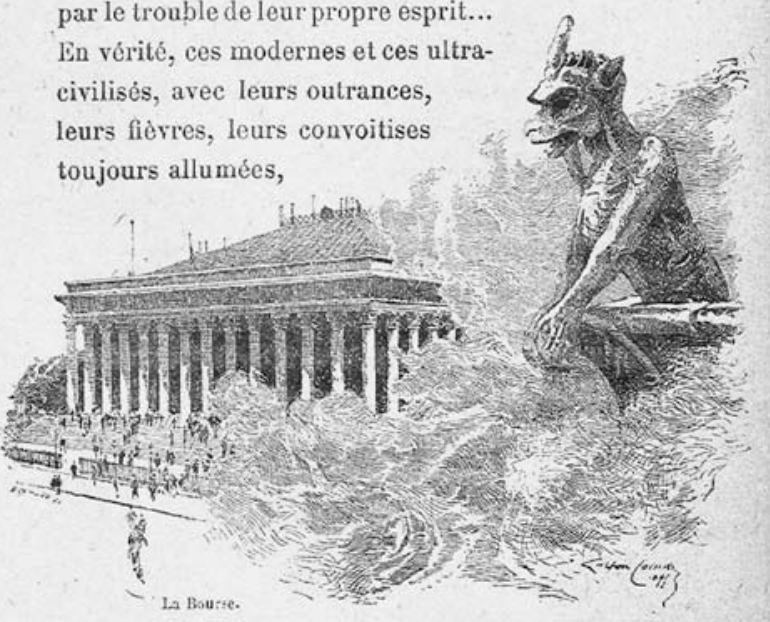

Uit: Édouard Drumont, De l'or, de la boue, du sang, Du Panama à l'anarchie (Flammarion, Parijs 1893). De illustratie hoort bij de opening van het hoofdstuk 'Le drame juive' 
in 1895 nog over de greep die 'de joden' hadden op de pers en de financiele wereld. ${ }^{8}$ Antisemitisme was voor Franse socialisten, zeker ten tijde van het Panama-schandaal heel gewoon en het ervan loskomen was gedurende de Dreyfus-affaire een moeizaam proces. Voor een belangrijke minderheid bleef het anti-joodse vooroordeel intact.

Voor socialisten was antisemitisme niet ongewoon, maar ook niet kenmerkend. Dat was het wel voor de massabeweging die Edouard Drumont ontketende, nadat hij zijn naam met $L a$ France Juive had gevestigd. In I889 richtte hij de 'Ligue antisémitique de France' op, die in de crisis van dat jaar rond de dreigende staatsgreep van generaal Boulanger een belangrijke agitatorische rol speelde. Ook in het Panama-schandaal roerde dezeliga zich duchtig, vooral nadat ze in I892 in La Libre Parole een dagelijkse spreekbuis kreeg. Maar ook bladen als L'Antijuif van Jules Guérin, La Cocarde van Maurice Barrès, L'Intransigeant van Henri Rochefort en het katholieke blad $\mathrm{La}$ Croix fungeerden in de jaren negentig van de negentiende eeuw als spreekbuis voor de liga. Drumont zette het succes van zijn France Juive, dat in 1893 aan de I33e druk toe was, voort met de publicatie in dat jaar van een bundeling van zijn krantenstukken in De l'or, de la boue, du sang, Du Panama à l'anarchie. 9

\section{De affaire als uiting van verzet tegen de heersende macht}

De Derde Republiek was geboren uit de nederlaag van het Tweede Keizerrijk en wist zich pas langzaam te stabiliseren. De heersende republikeinse politieke elite van de jaren na I880 zag zich geconfronteerd met een zwakke en versplinterde linkse oppositie na de mislukte Commune-opstand. Even zwak en verdeeld waren de royalisten en de Bonapartisten. De belangrijkste uitdaging voor het centrumrepublikeinse bewind was de ultranationalistische en deels socialistische beweging rond Generaal Boulanger. De man zelf was geen krachtfiguur maar de beweging achter hem was goed georganiseerd. Belangrijkste bestanddelen waren de Ligue des patriotes van Paul Deroulède en volgelingen van de revolutionaire socialist Auguste Blanqui. Ze wisten bij de verkiezingen van 1889 in januari successen te behalen. Maar aan het einde van het jaar, toen Boulanger naar België was gevlucht na een halfhartige poging tot een staatsgreep, zakte de beweging in elkaar. Toch roerden de 44 Boulangisten in de Kamer van Afgevaardigden - onder wie nogal wat antisemieten - zich duchtig in het Panama-schandaal, zij aan zij met de socialistische afgevaardigden. Deroulèdes liga werd na de mislukte staatsgreep verboden, maar zou in I 898 herleven en een stoottroep van de antidreyfusards worden.

De Boulangisten, zoals de jonge Maurice Barrès, paarden een fanatiek revanchisme - het terugwinnen van Elzas-Lotharingen op de gehate Duitse overwinnaars van I870 - aan een hervormingsgezindheid die het socialisme dicht naderde. Dit maakt hun gezamenlijk optreden met de diverse socialis- 
tische facties in de Kamer tijdens het Panama-schandaal begrijpelijker dan het op het eerste gezicht lijkt. Dat optreden was meer dan een gelegenheidssamenwerking tegenover een gemeenschappelijke vijand, het bewind van de centrumrepublikeinen, de 'Opportunistes'. Het Panama-schandaal maakte volgens de oppositie duidelijk hoe corrupt het republikeinse bewind was en hoe weinig die corruptie door de rechterlijke macht bestreden werd. Dat was overigens al eerder gebleken, toen in I887 uitkwam dat de schoonzoon van de Franse president Jules Grévy, Daniel Wilson, tot over zijn oren betrokken was bij de verkoop van verheffing tot lidmaatschap van het Légion d'honneur. In de agitatie had Deroulède, samen met zijn latere tegenstander Clemenceau een belangrijke rol gespeeld. De agitatie op straat en in de Kamer leidde uiteindelijk tot het aftreden van Grevy. Maar Wilson werd uiteindelijk vrijgesproken, nam zijn Kamerzetel weer in en was later nog enkel keren afgevaardigde.

Het geslonken aanzien van het bewind in de jaren tot I893 komt heel treffend naar voren in het lied dat overal in Parijs gezongen werd na de serie anarchistische aanslagen van I892-1893 en de onthoofding van de meest kleurrijke terrorist, Ravachol. Door vele georganiseerde anarchisten werd Ravachol als een ordinaire misdadiger beschouwd, die anarchistische motieven aanvoerde als dekmantel, maar dat nam niet weg dat Ravachol in wijde kring als een soort Robin Hood vereerd werd. In de tekst van het aan hem gewijde lied, gezongen op de wijze van de Carmagnole uit de tijd van de Franse Revolutie, moeten 'magistrats vendus', 'financiers ventrus', 'sénateurs gâteux' en 'députés véreux' het ontgelden. Voor al die omkoopbare rechters, volgevreten bankiers, seniele senatoren en malafide afgevaardigden geldt volgens dat lied: 'Vive le son de l' explosion'. ${ }^{10}$

\section{Het speelveld: pers, organisaties, straat en cabaret}

De periode van de schandalen van de medailles van 1887 tot de Dreyfus-affaire is het tijdperk van een ingewikkelde verwevenheid van politiek - zoals die zich in parlement en ministeries afspeelde en zoals die op straat door agitatie en demonstraties bedreven werd. Politici zijn vaak meteen journalist en hebben bij hun krant politieke en zakelijke belangen. Journalistiek is in deze tijd wat we tegenwoordig noemen vaak actiejournalistiek, in dienst van een ideologie of belang. De Panama-afffaire liet duidelijk zien hoe omkoopbaar de Franse pers was en hoe zeer economische invloed politieke macht opleverde. Anderzijds wist Drumont als onthuller van misstanden zijn krant La Libre Parole tijdelijk tot een succes te maken door de Panama-onthullingen. De Dreyfus-affaire zou nog talloze voorbeelden laten zien van het opkomen van nieuwe dagbladtitels en periodieken, of het doen stijgen van oplagen door nieuwe onthullingen. Schandalen voeden de honger naar kranten en betekenen extra beleg op het brood van journalisten. 
Het duel was een gewone manier om politieke meningsverschillen te beslissen. Hier Clemenceau en de Boulangist Paul Deroulède in 1892. Bron: www.1ge. org/documents / troisiemerepublique/ duelderoulede clemenceau.htm

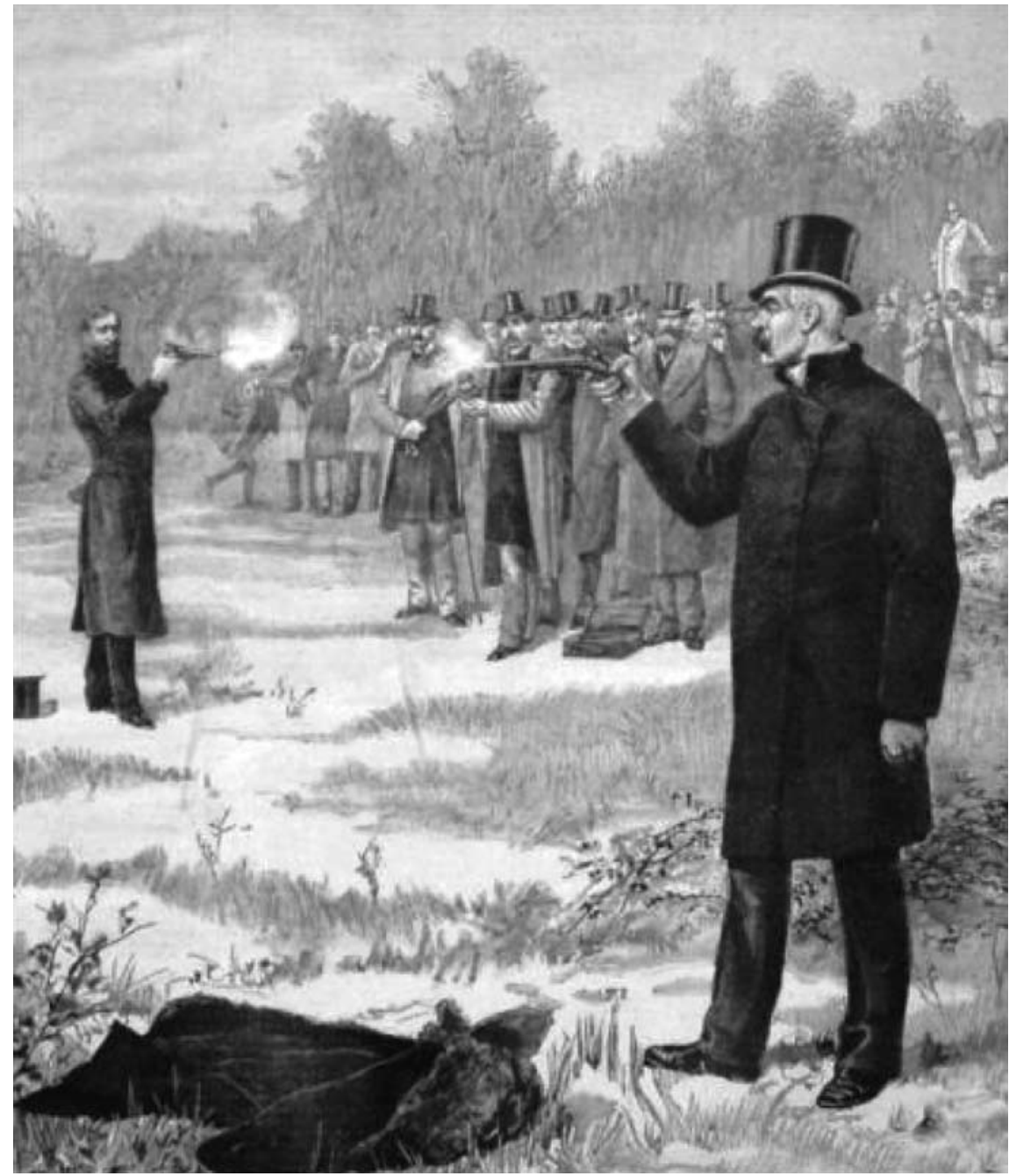

Nieuw na I887 is niet alleen de groei van de massapers maar ook die van de massa-organisatie. Daarbij valt de activiteit van de 'rechtse' liga's, zoals de Ligue des patriotes en de Ligue antisémitique meer op dan die van 'linkse' partijen en vakbonden, die nog tot wasdom moeten komen. Voor die nieuwe massaorganisaties geldt dat ze nauw verweven zijn met de politieke oppositie in de volksvertegenwoordiging en met de dagbladen en periodieken van de betreffende ideologische richting. Wat we al eerder zagen is dat links en rechts daarbij niet zo gemakkelijk van elkaar te onderscheiden zijn.

Wie de contemporaine berichtgeving over schandalen als die van Panama volgt kan het niet ontgaan dat de meningsvorming niet alleen in het parlement en de pers plaatsvond. Ook de straat was het toneel voor politieke uitingen als betogingen. In parken of op begraafplaatsen werden politieke conflicten in 
een gewapend duel voorgezet en in de cabarets weerklonken spotliederen op politici en bankiers. Grevy, de president van de Franse Republiek, was in I887 niet meer te handhaven toen 'tout Paris' het spotlied over de klaagzang van een schoonvader zong met als slotregel: "Ah quel malheur d'avoir un gendre". Frankrijk vertoont in deze jaren al heel wat kenmerken van wat tegenwoordig de 'audio-democratie' genoemd wordt. ${ }^{\text {II }}$

Scharnierpunt in de vorming van de publieke opinie zijn de çamelots, de lectuurverkopers op de straten van de Franse steden. Zij ventten kranten, pamfletten, brochures, spotliederen, spotprenten en goedkoop gedrukte boeken uit. $\mathrm{Zij}$ brachten het politieke debat op straat, buiten een parlement dat tot rond I900 nauwelijks landelijk georganiseerde politieke partijen kende. ${ }^{\text {I2 }}$

\section{Panama als mislukte zelfzuivering}

In de literatuur over affaires als historisch fenomeen komen we noties tegen, als zouden dit soort conflicten uiteindelijk bijdragen tot een meer evenwichtig maatschappelijk en politiek bestel. ${ }^{13}$ Ook Yves Mollier lijkt die stelling toegedaan in zijn uitvoerige beschrijving en analyse van de Panama-kwestie. Hij vergelijkt de Verenigde Staten met Frankrijk en betoogt dat dankzij affaires als die van Panama de Franse samenleving nadien beter af was dan de Amerikaanse, waarin corruptie endemisch bleef. Wie alleen al de Stavisky-affaire van I934 voor ogen houdt, weet beter. Het was in vele opzichten een replica van het Panama-schandaal. Een joodse oplichter, verwevenheid van corrupte politici, rechters en journalisten en een gevallen kabinet - en het gemeenschappelijke optreden op straat van communistische en fascistische knokploegen van de diverse ligues, die voortzettingen waren van de Ligue des patriotes van Deroulède en Drumont. ${ }^{\text {I4 }}$

Het Panama-schandaal leidde weliswaar tot de val van een kabinet, maar het kwam niet tot een poging tot staatsgreep zoals tijdens de Dreyfus-affaire in I899. Die was veel ernstiger dan de halfhartige poging van de Boulangisten van een decennium eerder, als die al serieus genomen moet worden. Maar de destabilisatie van de Derde Republiek, zoals die tijdens de Dreyfus-affaire bleek, was voor een niet gering gedeelte gestimuleerd door het Panama-schandaal. Dat de Derde Republiek overleefde, had vooral te maken met de steun die de meerderheid van de socialisten uiteindelijk aan de democratische rechtsorde gaf.

Het overleven van de Derde Republiek tijdens crises als die van de Panamajaren is daarnaast ook toe te schrijven aan de effectieve werking van het Franse repressie-apparaat. De diverse binnenlandse geheime diensten drongen diep door in de milieus van tegenstanders van de republiek van links en van rechts, als die al van elkaar te onderscheiden waren. De Parijse commissaris Andrieux, die ook tijdens het Panama-schandaal nog een belangrijke rol speelde, was in het midden van de jaren tachtig van de negentiende eeuw zelfs uitgever geweest 


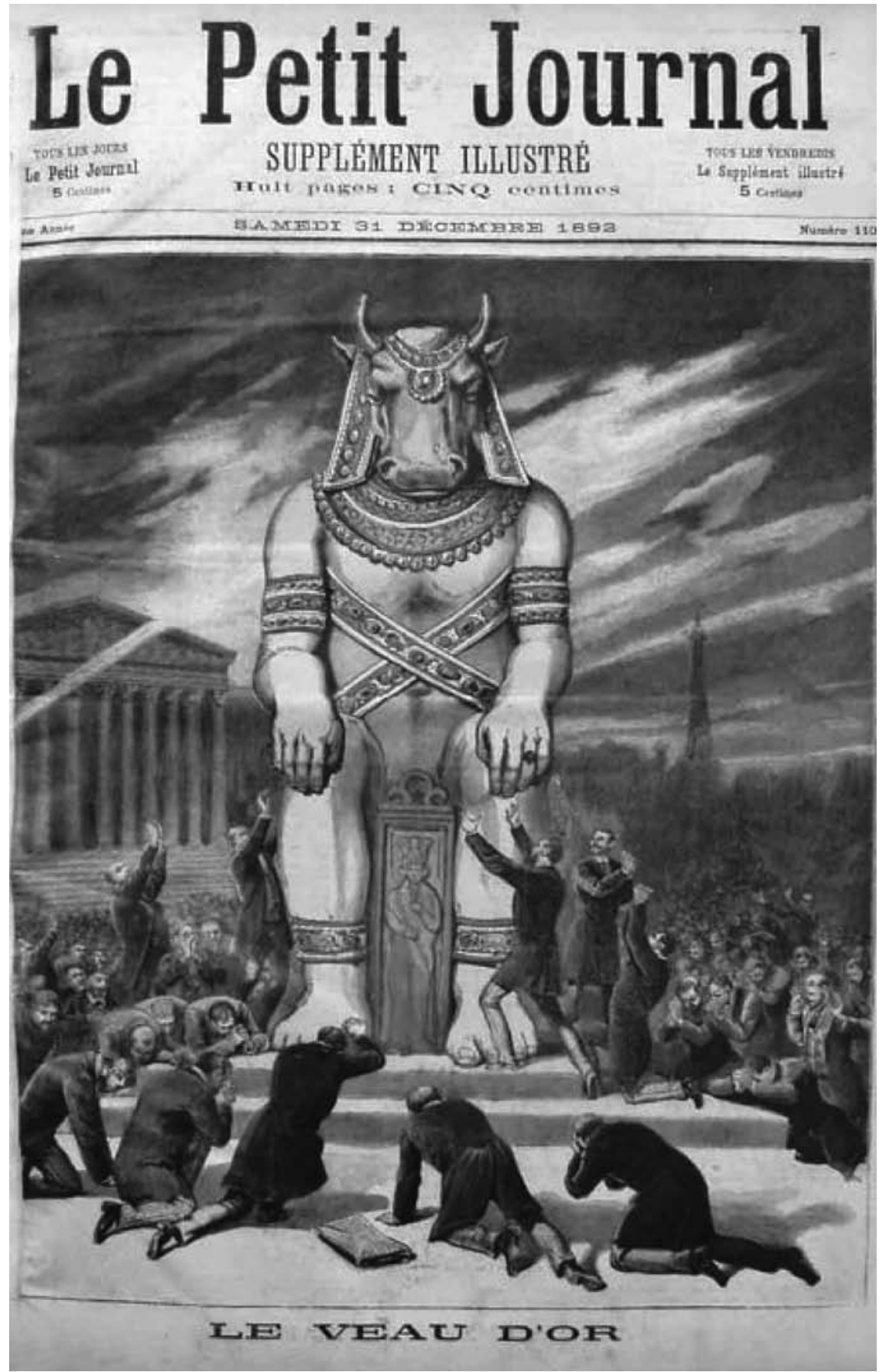

De aanbidding van het gouden kalf volgens Le Petit Journal in 1893. Het blad werd op straat verkocht door 'camelots'. Bron: www.1ge.org/documents/troisiemerepublique/panama.htm 
van een door de militanten serieus genomen anarchistisch tijdschrift. Wie wel eens onderzoek gedaan heeft in de archieven van de Préfecture de Police en de Sûreté Nationale komt onder de indruk van de vergaande infiltratie van de Franse diensten in oppositiekringen. De golf van anarchistische aanslagen in I892-I893 liet overigens zien dat zelfs de geheime dienst machteloos stond bij het terroristische optreden van geïsoleerde enkelingen, die op eigen initiatief handelden. Maar in vele andere gevallen bleken de diensten heel goed geïnformeerd over de handel en wandel van georganiseerde militanten in kringen van extreme nationalisten, antisemieten, anarchisten en socialisten. In de literatuur over die bewegingen zien we dat terug in de vele verwijzingen naar de betreffende archieven. Wat merkwaardigerwijze ontbreekt, is een diepgaande studie naar de manier waarop de Franse geheime diensten opereerden tijdens crises en schandalen als bijvoorbeeld het Panama-schandaal.

\section{Conclusie}

Al met al kan de periode van de Panama-schandalen van I889-1893 in de geschiedenis van Frankrijk en in die van Europa op tal van manieren gezien worden. Natuurlijk is het de opmaat tot de Dreyfus-affaire, die dan vooral geïnterpreteerd wordt als de strijd tussen rechts en links. Maar daarbij wordt dan vergeten, hoezeer de socialisten in de jaren van Panama bevangen waren door antisemitische vooroordelen, hoezeer de socialisten in die tijd ook vervuld waren van patriottische en anti-Duitse gevoelens, en hoezeer de rechtse nationalisten socialistisch georiënteerd waren. Het unieke van het Panama-schandaal zit hem in de dubbelzinnige rol van de journalistiek. Voor I889 gemakkelijk corrumpeerbaar, na I889 profiterend van de zelf-gecreëerde opwinding. Daarin was Panama de leerschool voor de Dreyfus-periode. Actiejournalistiek bleek te lonen.

\section{Epiloog}

In I893 kwamen de Nederlandse sociaal-democraten op hun jaarlijks Kerstcongres in Groningen bijeen. De parlementair gezinde minderheid, die zich het jaar daarop zou afsplitsen in de Sociaal-Democratische Arbeiders Partij (SDAP), probeerde partijleider Ferdinand Domela Nieuwenhuis beentje te lichten door hem te beschuldigen van betrokkenheid bij financiële malversaties in de naamloze vennootschap, die het partijblad Recht voor Allen drukte. De oppositionelen, geleid door P.J. Troelstra, gebruikten de slogan 'Panama', waarmee voor iedere tijdgenoot duidelijk was, wat hun beschuldiging inhield: bedrog, machtsmisbruik, omkoping en het hanteren van de doofpot. Troelstra sprak in april I893 al van 
'diefstal en verduistering van geld, door Arbeiders bijeengebracht (...) daar is ook Panama in onze eigen partij. (...) Wij zouden willen, dat in de partij omstandigheden wierden geschapen, die het voor de Panamisten in de partij onmogelijk maken, langer te panamaën'15.

De Panama-beschuldiging bleek uiteindelijk als een zeepbel uiteen te spatten, maar Troelstra's proza laat zien hoe sterk het begrip 'Panama' in het publieke taalgebruik was doorgedrongen. Troelstra werd er nog wel eens aan herinnerd: 'Meer dan eens is het mij gebeurd, dat ik te Amsterdam zijnd, op straat werd nageroepen met den hatelijken deun: Poainemoai!'16

\section{Noten}

I A. Goldgar, Tulipmania. Money, Honor and Knowledge in the Dutch Golden Age, Chicago 2007.

2 Het beste overzicht is J.-Y. Mollier, Le scandale de Panamá, Parijs I991. Voor de technische kant zie: D. McCullough, The Path Between the Seas: The Creation of the Panama Canal, 1870-1914, New York I977.

3 Een mooi overzicht van de vele processen en hoorzittingen biedt het repertorium van in de Archives Nationales te Parijs aanwezige stukken: http://www.archivesnationales.culture.gouv. $\mathrm{fr} / \mathrm{camt} / \mathrm{fr} /$ inventairesaq/7aq.html (geraadpleegd I oktober 2007).

4 M. Winock, La France et les Juifs de 1789 à nos jours, Parijs 2004. Cap. II 'Le temps de l'intégration', p. 29-49.

5 Voor La Croix zie: P. Sorlin, La croix et les Juifs (1880-1899): contribution à l'histoire de l'antisémitisme contemporain, Parijs I967.

6 Geciteerd in Winock, France et Juifs, p. 47.

7 Z. Sternhell, La droite révolutionnaire 1885-1914. Les origines françaises du fascisme, Parijs I970. Cap. Iv 'L'antisémitisme de gauche', p. II77-I2I4.

8 J. Jaurès, 'La question juive en Algérie', La Dépêche, I mei I895, geciteerd in Winock, France et Juifs, p. 91.

9 Éd. Drumont, De l'or, de la boue, du sang, Du Panama à l'anarchie, Parijs I893.

Io Voor de volledige tekst http://www.I9 ${ }^{\mathrm{e}}$.org-documets-troisiemerepublique/anarattentats/ ravachole.htm (geraadpleegd I oktober 2007).

II Een aardige beschrijving van deze verwevenheid biedt G. Guilleminault, La Jeunesse de Marianne, Parijs I958, p. 220-273.

I2 J.-Y. Mollier, Le camelot et la rue - Politique et démocratie au tournant des Ixe et xxe siècles, Parijs 2004 .

I3 S. Neckel, 'Political Scandal, An Analytical Framework', Comparative Sociology, Vol. 4/I-2 (Leiden 2005) p. IOI-III.

I4 P. Jankowski, Cette vilaine affaire Stavisky, Histoire d'un scandale politique, Parijs 2000.

I5 P.J. Troelstra, 'Betere Menschen', De Nieuwe tijd, I april I893.

I6 P.J. Troelstra, 'De wording der s.D.A.P.' Na tien jaar. Gedenkschrift bij het tienjarig bestaan der Sociaal-Democratische Arbeiderspartij, Amsterdam I904, p. I2I. 